\title{
Studi Modifikasi Geometri Sudu pada Turbin Air Propeller Menggunakan Metode Elemen Hingga
}

\author{
Febri Budi Darsono $^{1 *}$, Akhmad Nurdin ${ }^{2}$, Rahmat Doni Widodo ${ }^{1}$, Rusiyanto ${ }^{1}$ \\ ${ }^{1}$ Jurusan Teknik Mesin, Universitas Negeri Semarang (UNNES) \\ Sekaran, Kec. Gunung Pati, Kota Semarang, Jawa Tengah 50229 \\ ${ }^{2}$ Program Studi Teknologi Pengecoran Logam, Politeknik Manufaktur Ceper \\ Batur, Tegalrejo, Kec. Ceper, Kabupaten Klaten, Jawa Tengah 57465
}

*E-mail: febribudi@mail.unnes.ac.id

Diterima: 02-03-2021; Direvisi: 27-11-2021; Dipublikasi: 30-12-2021

\begin{abstract}
Abstrak
Desain kekuatan turbin air propeller berdasarkan ketahanan terhadap pembebanan gaya aksial dari air. Pembebanan gaya aksial pada turbin air propeller menyebabkan tegangan bending pada sudu dan berpotensi terjadi kegagalan sudu pada struktur turbin. Tujuan dari penelitian ini untuk membandingkan kekuatan modifikasi desain geometri turbin air propeller, yaitu penambahan fillet pada sisi hub sudu dan penambahan ketebalan sudu. Pengambilan data penelitian ini dengan Metode Elemen Hingga menggunakan Solid Works Simulation 2016 dan pembebanan pada sudu dengan tekanan statik. Hasil akhir penelitian ini menunjukkan bahwa modifikasi desain geometris dengan penambahan ketebalan sudu lebih meningkatkan faktor keamanan dibandingkan penambahan fillet pada sisi hub sudu.
\end{abstract}

Kata kunci: gaya aksial; metode elemen hingga; propeller; tegangan bending

\begin{abstract}
The strength design of the water propeller turbine based on endurance from axial force loading of water. The axial force loading on the propeller water turbine induces the bending stress on the blade and potentially occurs the failure at the blade in the turbine structure. The purpose of this study to compare the strength of the design modification of the propeller water turbine geometry, that is added the fillet on the hub blade side and the addition blade thickness. Retrieval of data this study with Finite Element Method using Solid Works Simulation 2016 and the loading on the blade with static pressure. The final result of this study indicates a modification of the geometric design with the addition of blade thickness increases the safety factor more than the addition of the fillet at the tip blade side
\end{abstract}

Keywords: axial force; bending strees; finite elemen method; propeller

\section{Pendahuluan}

Sumber energi alternatif saat ini terus dikembangkan secara nasional maupun secara global, salah satu enegi alternatif adalah energi air [1]. Ditinjau dari nilai ekonominya, energi air merupakan salah satu jenis energi terbarukan termurah, banyak tersedia [2] dan paling efisien dibandingkan energi terbarukan lainnya [3]. Berdasarkan kategori skala dayanya pembangkit listrik tenaga air terkecil menghasilkan maksimal $5 \mathrm{~kW}$ dan selanjutnya disebut pico-hydro [4]. Pico-hydro memiliki konsep sederhana karena tidak memerlukan pembendungan aliran air, tenaga ahli, dan perancangan sederhana sehingga biaya implementasi pembangunannya relatif murah [5][6], dan salah satu perancangan sederhana ini adalah perancangan turbin. Salah satu kategori turbin air berdasarkan arah aliran air yaitu aliran aksial [7], sedangkan jenis turbin yang sering digunakan pada aliran aksial adalah turbin propeller dengan keunggulan meliputi kinerja tinggi, bentuk praktis, dan proses produksi relatif murah dibandingkan jenis turbin air lainnya [8][9].

Perkembangan teknologi polimer sebagian kecil telah menggantikan logam [10] terutama pada benda yang memiliki beban kerja ringan. Pada pico-hydro dengan daya available dibawah 100 Watt [11] memungkinkan material yang pada turbin menggunakan polimer. Pada aplikatifnya teknologi polimer semakin meningkat penggunaanya seiring 
semakin mudah proses pembentukannya, yaitu menggunakan teknologi 3D printing dengan proses lebih mudah [12], hasil lebih presisi, dan biaya lebih murah dibandingkan dengan proses permesinan konvensional. Hasil presisi dan biaya relatif lebih murah, teknologi 3D printing dengan material polimer dapat diaplikatifkan untuk pembuatan tubin air picohydro yang sesuai dengan konsep sederhananya.

Saat turbin air propeller bekerja setiap sudu turbin menerima tumbukan air dari arah tegak lurus terhadap posisi permuakaannya, hal ini disebut sebagai beban aksial [13]. Beban aksial yang melebihi ketahanan material pada turbin propeller menyebabkan kegagalan dan memungkinkan sudu turbin mengalami patahan seperti yang ditunjuukan Gambar 1. Selain ditinjuai dari sisi ketahan material kegagalan dapat disebabkan kesalahan pada desain, resiko kegagalan ini dapat dikecilkan dengan memodifikasi desain turbin propeller.

Studi ini bertujuan menganalisaa kekuatan modifikasi desain pada turbin propeller berdasarkan nilai safety faktornya. Modifikasi desain turbin pada studi ini meliputi penambahan fillet dibagian akar sudu dan penambahan ketebalan sudu. Pengambila data pada studi ini menggunakan metode elemen hingga melalui computation dengan perangkat lunak soliworks simulation 2016. Secara langsung studi ini berkontribusi dalam pengembangan kekuatan desain pada turbin propeller.

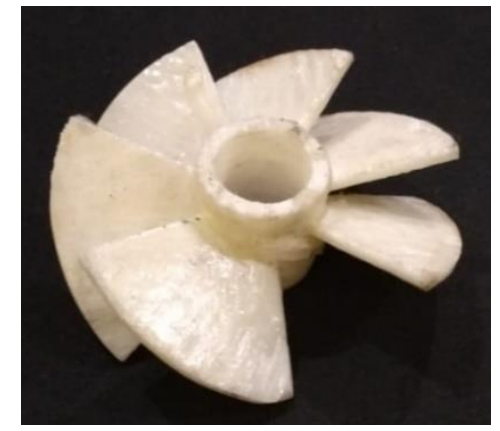

Gambar 1. Kegagalan akibat beban aksial sudu turbin air propeller

\section{Material dan metodologi}

Turbin yang mengalami kegagalan digunakan pada studi ini bagian dari penelitian pada referensi [4] seperti skema desain 3D yang ditunjukkan Gambar 2 dengan jumlah sudu 6 buah, kemiringan sudu $25^{\circ}$, dan menggunakan material polimer ABS 3D Printing manufacture dengan material properties pada solidworks 2016 yang di tunjukkan Tabel 1.

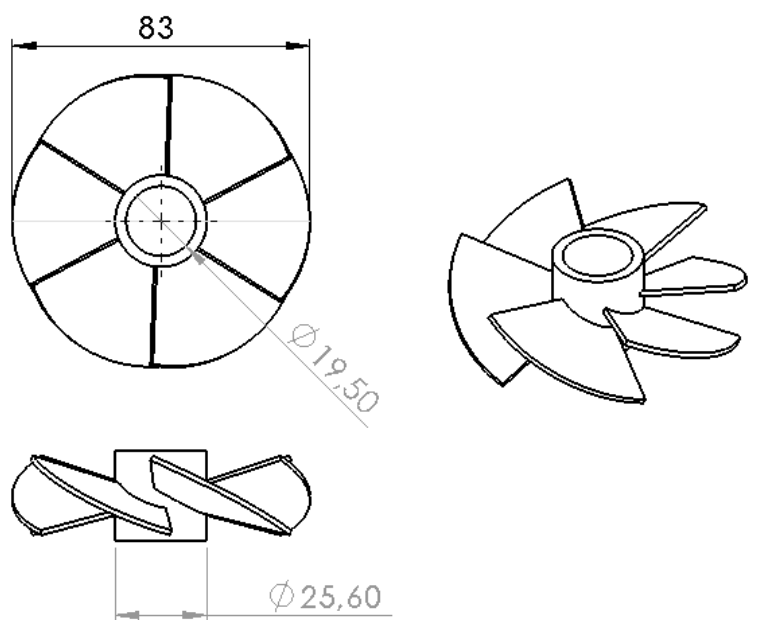

Gambar 2. Skema desain turbin air propeller 
Tabel 1. Material properties ABS polymer

\begin{tabular}{cc}
\hline Properties & Nilai \\
\hline Elastic Modulus & $2410 \mathrm{~N} / \mathrm{mm}^{2}$ \\
Poisson's Ratio & 0.35 \\
Shear Modulus & $318,5 \mathrm{~N} / \mathrm{mm}^{2}$ \\
Mass Density & $862,2 \mathrm{~kg} / \mathrm{m}^{3}$ \\
Tensile Strength & $55,2 \mathrm{~N} / \mathrm{mm}^{2}$ \\
Yield Strength & $200 \mathrm{~N} / \mathrm{mm}^{2}$ \\
Thermal Conductivity & $0.2618 \mathrm{~W} /(\mathrm{m} \cdot \mathrm{K})$ \\
Specific Heat & $1900 \mathrm{~J} /(\mathrm{kg} \cdot \mathrm{K})$ \\
\hline
\end{tabular}

Parameter yang digunakan pada modifikasi sudu ini penambahan multiple radius fillet pada bagian hub dengan variasi ukuran 0 sampai $2 \mathrm{~mm}$ dan penambahan ketebalan sudu dengan variasi ketebalan 1,5 sampai $3 \mathrm{~mm}$. Parameter modifikasi sudu turbin propeller ini ditunjukkan Gambar 3.

Pada simulasi metode elemen hingga diperlukan validasi pada pengaturan meshing sebagai acuan meshing yang akurat dari hasil simulasi yang dilakukan [14]. Desain untuk pengaturan meshing simulasi ini mengacu penelitian yang ditunjukkan referensi [10], yaitu desain pada poros tengah. Pengaturan meshing dilakukan dengan variabel ukuran global mesh dan tolerance mesh dengan nilai strees seperti yang ditujukkan Tabel 2. Pada pengaturan dengan ukuran global mesh 1,22 $\mathrm{mm}$ dan tolerance mesh $0,05 \mathrm{~mm}$ menunjukkan nilai paling mendekati nilai stress poros tengah dengan pengaturan kondisi batas yang sama pada penelitian [10] seperti yang ditunjukkan Gambar 4. Sehingga pengaturan meshing pada simulasi ini dengan ukuran global mesh 1,22 mm dan tolerance mesh 0,05 mm.

Selain itu, simulasi elemen hingga pada studi ini dimodelkan yang ditunjukkan Gambar 5 dengan sebuah sudu menggunakan pembebanan gaya statis dengan nilai 0,106 MPa yang diterima sudu, fixture atau tumpuan yang digunakan tumpuan fixed pada bagian penempatan poros. Sedangkan hasil meshing sesuai dengan pengaturan validasi ditujunjukkan Gambar 6.

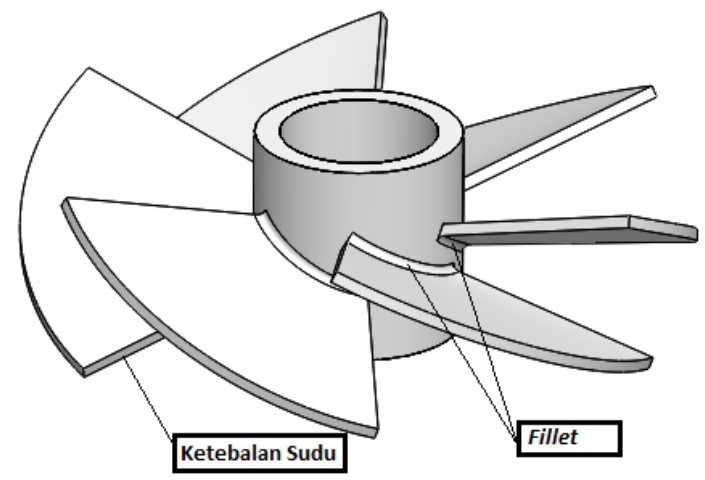

Gambar 3. Parameter modifikasi sudu

Tabel 2. Pengaturan meshing dan nilai strees maksimal

\begin{tabular}{cccccccccccc}
\hline Parameter & Nilai & Nilai & Nilai & Nilai & Nilai & Nilai & Nilai & Nilai & Nilai & Nilai & Nilai \\
\hline $\begin{array}{c}\text { Global Mesh } \\
(\mathrm{mm})\end{array}$ & 2,83 & 2,55 & 2,29 & 2,07 & 1,86 & 1,67 & 1,51 & 1,35 & 1,22 & 1,09 & 0,98 \\
\hline $\begin{array}{c}\text { Tolerance Mesh } \\
(\mathrm{mm})\end{array}$ & 0,13 & 0,11 & 0,1 & 0,09 & 0,08 & 0,07 & 0,06 & 0,06 & 0,05 & 0,04 & 0,04 \\
\hline $\begin{array}{c}\text { Strees Plot Max } \\
(\mathrm{MPa})\end{array}$ & 1,116 & 1,125 & 1,156 & 1,107 & 1,202 & 1,318 & 1,307 & 1,406 & 1,567 & 1,659 & 1,687 \\
\hline
\end{tabular}


Darsono dkk. /Jurnal Rekayasa Mesin

p-ISSN: 1411-6863, e-ISSN: 2540-7678

Vol.16|No.3|311-318|Desember|2021
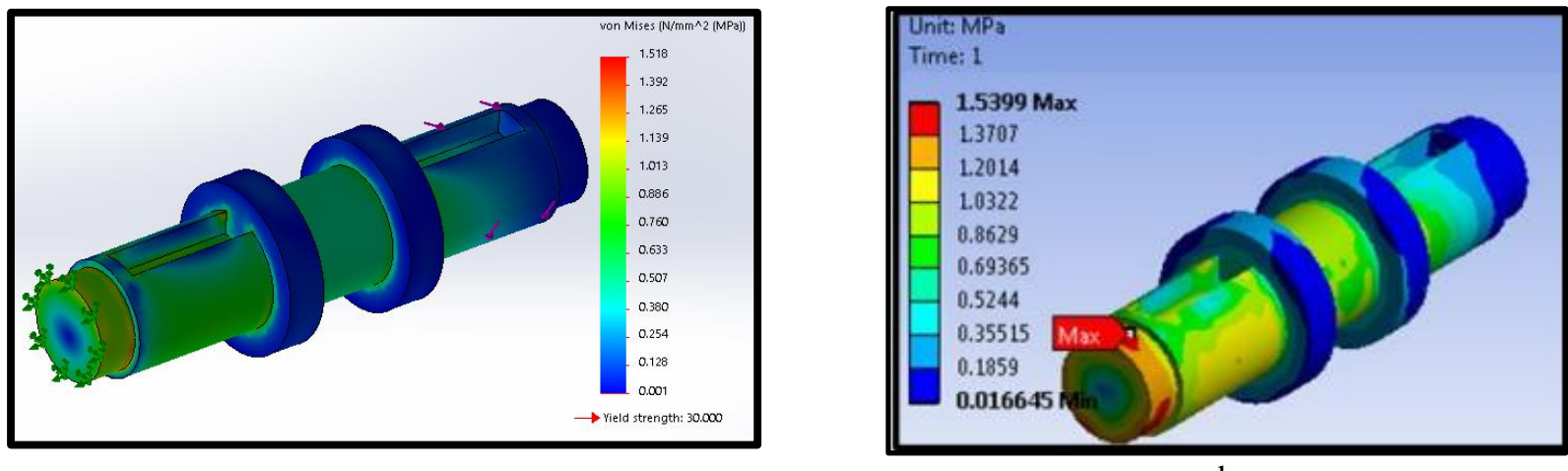

a

b

Gambar 4. Validasi pengaturan meshing (a) Validasi acuan [10] (b) Hasil validasi dengan global mesh 1,22 mm dan tolerance mesh $0,04 \mathrm{~mm}$

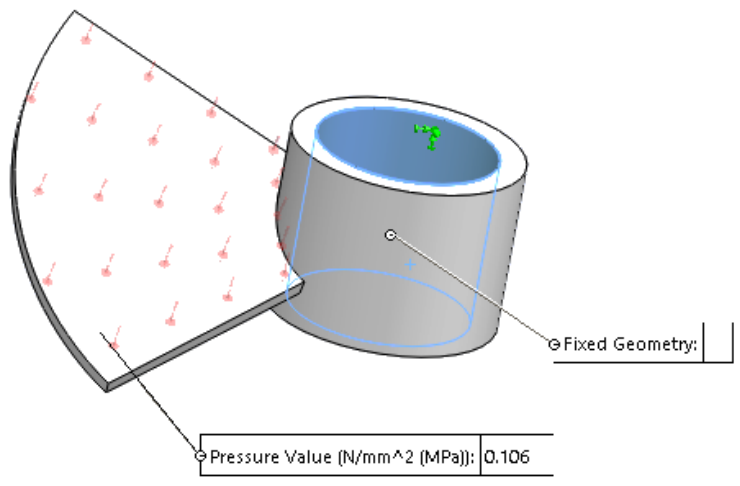

Gambar 5. Kondisi batas simulasi elemen hingga

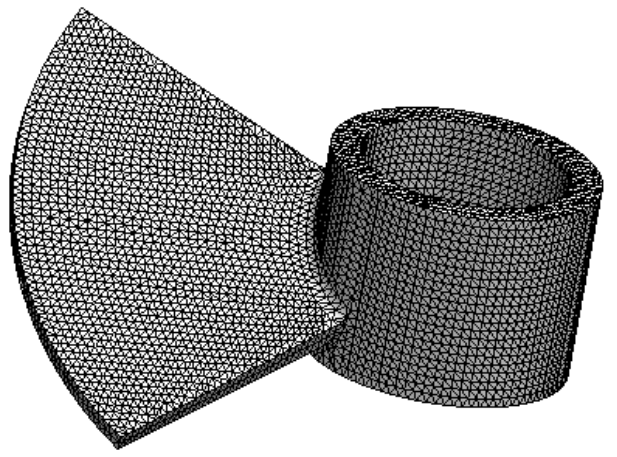

Gambar 6. Hasil meshing

\section{Hasil dan pembahasan}

Hasil akhir dari simulasi menampilkan nilai tegangan maksimal yang diterima setiap sudu dari desain turbin ditunjukkan Tabel 3 dengan nilai safety factor seperti yang ditunjukkan Tabel 4. Safety factor pada sudu ini merupakan nilai perbandingan antara tegangan luluh material sudu dengan tegangan maksimal yang diterima sudu, sehingga nilai safety factor selalu berbanding terbalik dengan tegangan maksimal yang diterima sudu [15], hal ini ditunjukkan pada perbandingan Tabel 3 dan Tabel 4, semakin kecil nilai tegangan yang diterima sudu, maka nilai safety factor semakin tinggi. Tabel 4 menunjukkan nilai safety factor dengan parameter ketebalan sudu dan ukuran fillet, pada sudu tanpa modifikasi (tanpa fillet dan ketebalan $1,5 \mathrm{~mm}$ ) nilai safety factor tidak lebih dari 1. Nilai safety factor kurang dari 1 juga 
Darsono dkk. /Jurnal Rekayasa Mesin

p-ISSN: 1411-6863, e-ISSN: 2540-7678

Vol.16|No.3|311-318|Desember|2021

terjadi pada parameter ukuran fillet 0,5 dan $0,98 \mathrm{~mm}$ dengan ketebalan sudu 1,5 mm. Nilai safety factor dibawah 1 ditinjau dengan beban statik menunjukkan kemampuan maksimal desain menahan beban masih dibawah beban yang diterima, hal ini menyebabkan resiko terjadinya kegagalan sangat besar. Nilai safety factor lebih dari 2 ditunjukkan pada sebagain ketebalan sudu 2,5 mm dan semua pada ketebalan sudu $3 \mathrm{~mm}$.

Kontur tegangan dan safety factor dengan nilai pembebanan yang sama pada beberapa parameter ditunjukkan Gambar 7, Gambar 8, dan Gambar 9. Gambar 7 menunjukkan nilai tegangan yang diterima sudu yang belum dimodifikasi lebih besar dibandingkan setelah dimodifikasi dengan safety factor terkecil terletak pada bagian hub atau akar dari sudu. Pada daerah akar sudu terjadi tegangan bending selama menerima beban, hal ini disebabkan pada daerah tersebut berupa lengkungan sehingga konsentrasi pada daerah tersebut menjadi tinggi [10] dan safety factor terkeceil juga terletak pada daerah tersebut.

Gambar 8 menunjukkan sudu yang telah dimodifikasi dengan ukuran fillet 1,5 mm dan ketebalan sudu 2,5 mm, nilai tegangan yang terjadi lebih kecil dibandingkan pada sudu sebelum dimodifikasi dengan nilai beban yang sama dan nilai tegangan ini akan semakin turun seiiring dengan bertambahnya ukuran fillet dan ketebalan sudu seperti yang ditunjukkan Gambar 9, hal ini disebabkan dengan adanya penambahan fillet dan penebalan sudu bagian akar sudu semakin tebal sehingga luasan daerah tersebut semakin naik, pada perhitungan dasar tegangan dengan nilai pembebanan yang sama semakin naik nilai luasan (nilai pembagi) maka semakin turun nilai tegangannya dan nilai safety factor semakin naik.

Tabel 3. Nilai tegangan dari parameter fillet dan ketebalan sudu

\begin{tabular}{|c|c|c|c|c|c|c|}
\hline & & \multicolumn{5}{|c|}{ Fillet $(\mathrm{mm})$} \\
\hline & & 0 & 0,5 & 1 & 1,5 & 2 \\
\hline \multirow{4}{*}{ 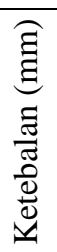 } & 1,5 & $268,2541 \mathrm{MPa}$ & $255,007 \mathrm{MPa}$ & $199,546 \mathrm{MPa}$ & $179,709 \mathrm{MPa}$ & $170,726 \mathrm{MPa}$ \\
\hline & 2 & $169,445 \mathrm{MPa}$ & $167,380 \mathrm{MPa}$ & $129,893 \mathrm{MPa}$ & $118,994 \mathrm{MPa}$ & $108,804 \mathrm{MPa}$ \\
\hline & 2,5 & $117,46 \mathrm{MPa}$ & $110,511 \mathrm{MPa}$ & $93,456 \mathrm{MPa}$ & $82,61 \mathrm{MPa}$ & 77,102MPa \\
\hline & 3 & $80,897 \mathrm{MPa}$ & $78,156 \mathrm{MPa}$ & $66,239 \mathrm{MPa}$ & $62,99 \mathrm{MPa}$ & $59,954 \mathrm{MPa}$ \\
\hline
\end{tabular}

Tabel 4. Nilai safety factor dari parameter fillet dan ketebalan sudu

\begin{tabular}{|c|c|c|c|c|c|c|}
\hline & & \multicolumn{5}{|c|}{ Fillet $(\mathrm{mm})$} \\
\hline & & 0 & 0,5 & 1 & 1,5 & 2 \\
\hline \multirow{4}{*}{ 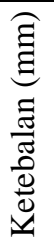 } & 1,5 & 0,77 & 0,81 & 0,98 & 1,10 & 1,10 \\
\hline & 2 & 1,10 & 1,10 & 1,50 & 1,50 & 1,60 \\
\hline & 2,5 & 1,60 & 1,70 & 2,00 & 2,20 & 2,30 \\
\hline & 3 & 2,10 & 2,10 & 2,70 & 2,90 & 3,34 \\
\hline
\end{tabular}

Pada studi ini menunjukkan semakin besar ukuran fillet dan ketebalan sudu, maka safety factor dari desain tersebut akan naik. Gambar 10 dan Gambar 11 masing-masing menunjukkan desain turbin tampak dari samping dengan perbedaan variasi setiap parameternya dengan nilai safety factor lebih dari 2. Gambar 10 menunjukkan pada sudu dengan ukuran fillet $2 \mathrm{~mm}$ dan ketebalan $3 \mathrm{~mm}$ memiliki celah yang lebih sempit dibandingkan pada ukuran fillet 1,5 mm dan ketebalan 2,5 mm. Nilai ketebalan antar sudu pada turbin air propeller akan mempengaruhi nilai soliditas turbin, perubahan soliditas ini secara langsung menyebabkan kinerja turbin berubah [16]. Pada studi ini nilai soliditas 
Darsono dkk. /Jurnal Rekayasa Mesin p-ISSN: 1411-6863, e-ISSN: 2540-7678

Vol.16|No.3|311-318|Desember|2021

Gambar 11 lebih besar dibandingkan Gambar 10, turbin yang ditunjukkan Gambar 11 tersebut celah antar sudu semakin sempit dan beresiko terjadinya aliran turbulen pada bagian discharge [16] sehingga berpotensi menurunkan kinerja turbin. Berdasarkan hal tersebut, sudu turbin dengan ukuran fillet 1,5 mm dan ketebalan 2,5 mm lebih layak digunakan dibandingkan sudu turbin dengan ukuran fillet $2 \mathrm{~mm}$ dan ketebalan $3 \mathrm{~mm}$.
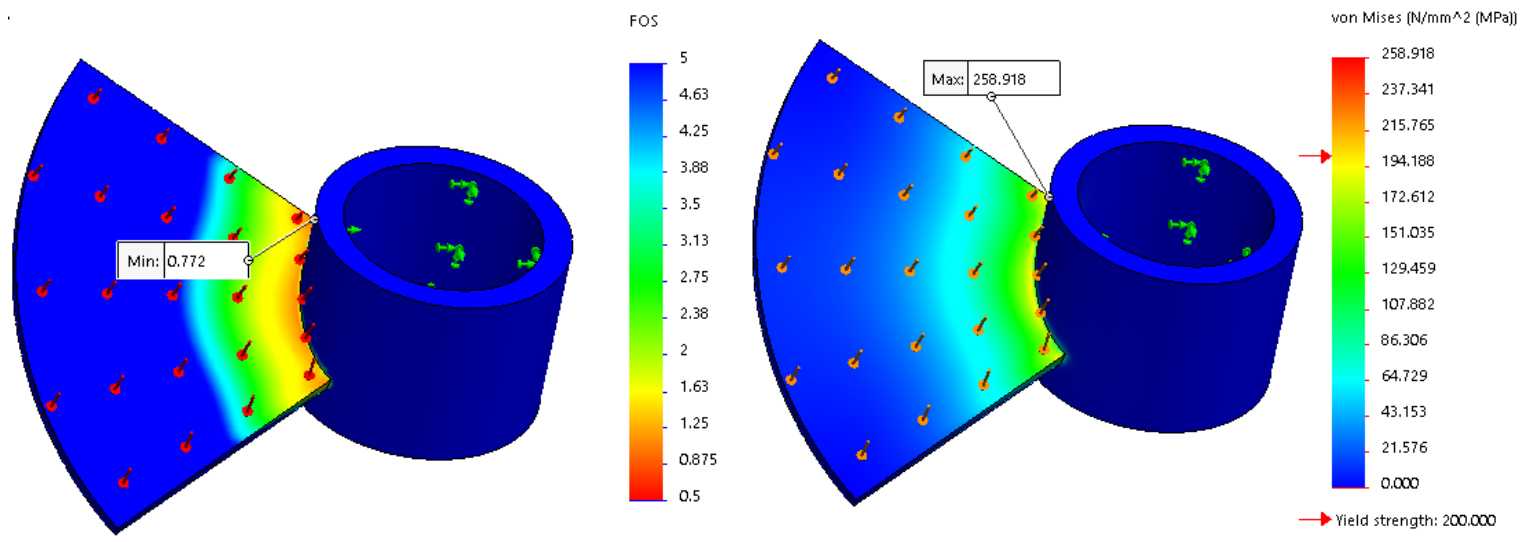

Gambar 7. Hasil simulasi elemen hingga pada fillet $0 \mathrm{~mm}$ dan ketebalan $1,5 \mathrm{~mm}$
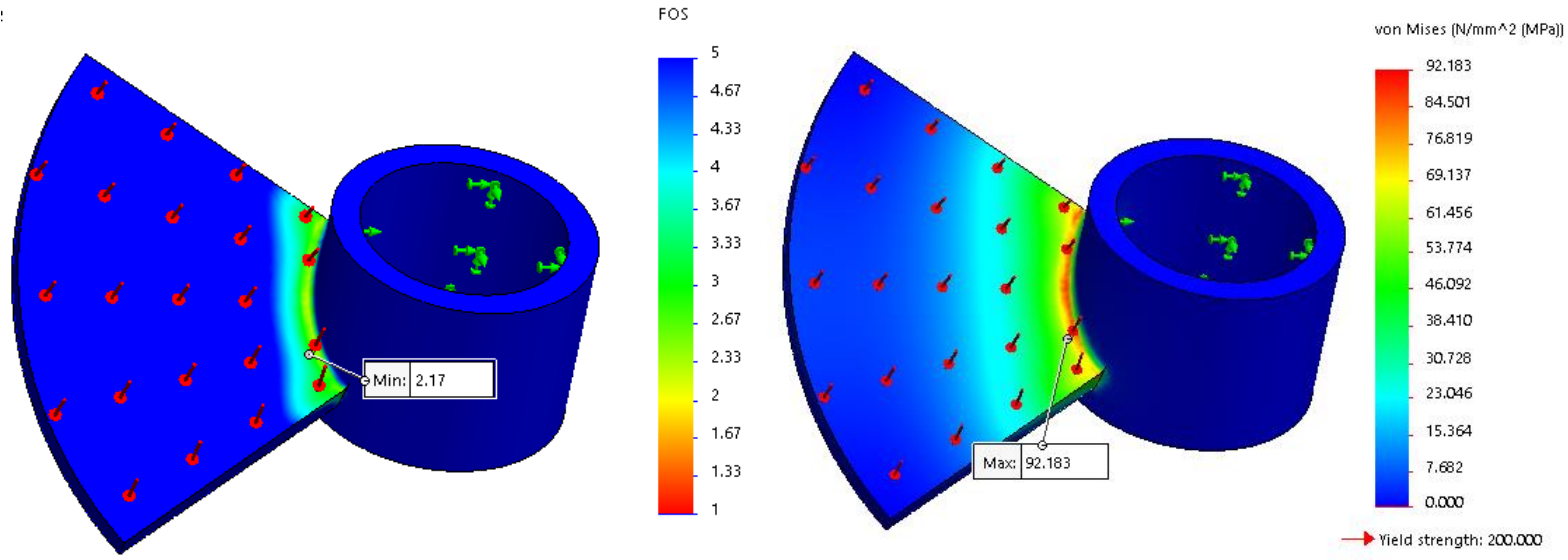

Gambar 8. Hasil simulasi elemen hingga pada fillet 1,5 $\mathrm{mm}$ dan ketebalan 2,5 mm

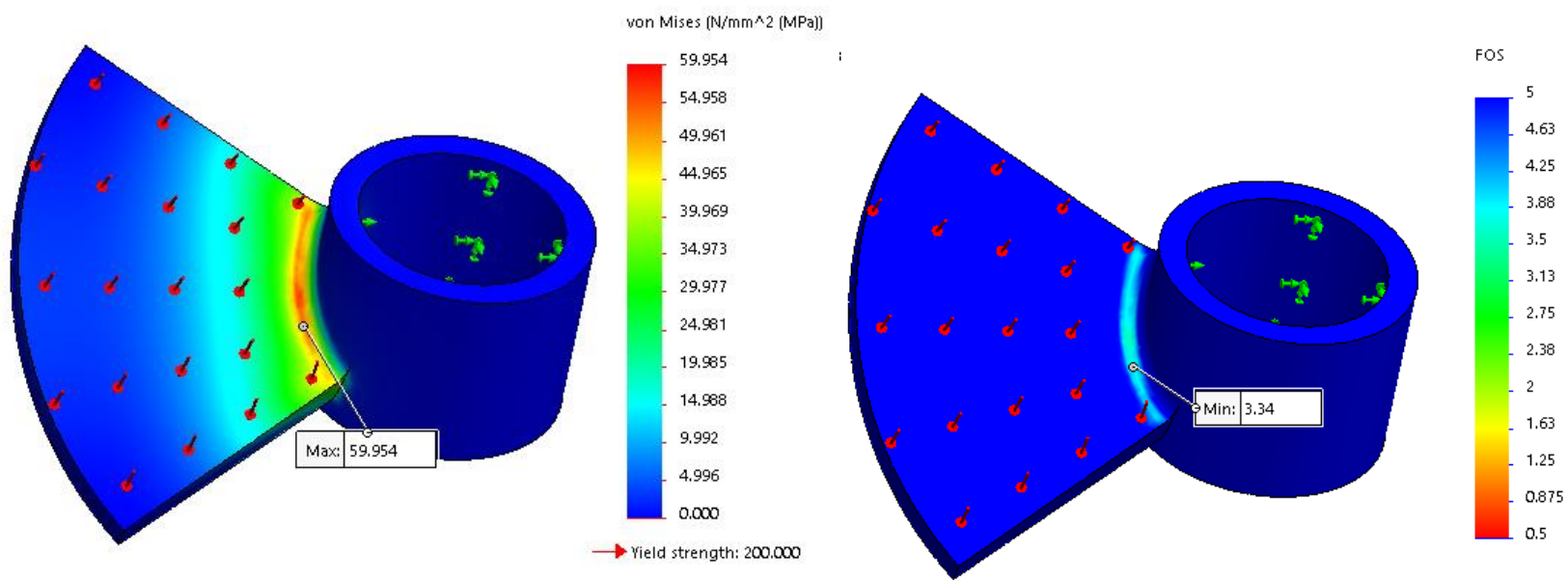

Gambar 9. Hasil simulasi elemen hingga pada fillet $2 \mathrm{~mm}$ dan ketebalan $3 \mathrm{~mm}$ 


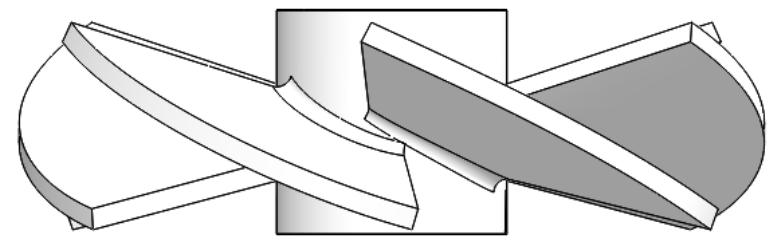

Gambar 10. Desain turbin propeller pada fillet $1,5 \mathrm{~mm}$ dan ketebalan $2,5 \mathrm{~mm}$

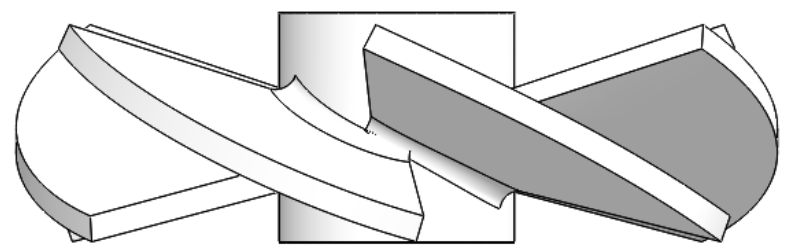

Gambar 11. Desain turbin propeller pada fillet $2 \mathrm{~mm}$ dan ketebalan $3 \mathrm{~mm}$

\section{Kesimpulan}

Berdasarkan hasil studi simulasi ini menunjukkan tegangan bending terbesar terjadi pada bagian akar sudu dengan nilai safety factor terkecil pada bagian akar sudu pula. Studi ini juga menunjukkan penambahan fillet dan penambahan ketebalan pada sudu mampu menurunkan nilai tegangan bending yang terjadi pada akan gigi, sehingga menaikkan nilai safety factor. Seiring penambahan ukuran fillet dan ketebalan sudu menunjukkan desain turbin dengan celah antar sudu yang semakin kecil maka nilai soliditas turbin juga semakin naik. Penelitian ini juga menunjukkan bahwa modifikasi desain geometris dengan penambahan ketebalan sudu lebih meningkatkan faktor keamanan dibandingkan penambahan fillet pada sisi hub sudu.

\section{Daftar Pustaka}

[1] F. Widyantama and D. Suanggana, "Simulasi CFD Pengaruh Penggunaan Deflektor Pelat Lengkung terhadap Performa Turbin Air Savonius Sumbu Vertikal Dua Sudu Fakhrul Widyantama dkk / Jurnal Rekayasa Mesin,” vol. 16, no. 2, pp. 234-240, 2021.

[2] P. Erinofiardi, Gokhale, A. Date, and A. Akbarzadeh, "A review on micro hydropower in Indonesia," in 1st International Conference on Energy and Power, ICEP2016, 2017, vol. 110, no. December 2016, pp. 316-321.

[3] D. S. Pamuji, H. L. Nugroho, and D. Sugati, "Studi Numerik Perbandingan Kinerja dan Medan Aliran Turbin Vortex Gravitasi dengan Tipe Sudu Lengkung Backward dan Forward Didit Setyo Pamuji dkk / Jurnal Rekayasa Mesin,” vol. 16, no. 1, pp. 48-55, 2021.

[4] A. Nurdin, D. A. Himawanto, and S. Hadi, "Optimasi perancangan turbin air menggunakan analysis of variance aliran horisontal,” vol. 10, no. 2, pp. 103-109, 2020.

[5] H. P. Dewanto, D. A. Himawanto, and D. Danardono, "Pembuatan dan pengujian turbin propeller dalam pengembangan teknologi pembangkit listrik tenaga air piko hidro ( PLTA-PH ) dengan variasi debit aliran," JTMI, vol. 12, no. 2, pp. 54-62, 2017.

[6] B. Ho-Yan, "Design of a Low Head Pico Hydro Turbine for Rural Electrification in Cameroon," The University of Guelph, 2012. 
Darsono dkk. /Jurnal Rekayasa Mesin

p-ISSN: 1411-6863, e-ISSN: 2540-7678

Vol.16|No.3|311-318|Desember|2021

[7] A. Nurdin, D. A. Himawanto, and S. Hadi, "Study of the Effect of Bulb Ratio and Blade Angle on Propeller Turbine Performance in Horizontal Flow using Numerical Simulation,” vol. 41, no. 1, pp. 9-13, 2020.

[8] A. Nurdin, D. A. Himawanto, and S. Hadi, "The Utilization of Horizontal Pipeline for A Static Bulb Turbine and The Determination Of Optimum Blade Number,” vol. 18, no. 2, pp. 61-68, 2020.

[9] S. J. Williamson, B. H. Stark, and J. D. Booker, "Low head pico hydro turbine selection using a multi-criteria analysis," Renew. Energy, vol. 61, pp. 43-50, 2014.

[10] A. Nurdin and D. A. Himawanto, "Studi numerik kekuatan material transmisi roda gigi pico hydro," JTMI, vol. 14, no. 1, pp. 24-29, 2019.

[11] A. Nurdin, D. A. Himawanto, and S. Hadi, "Experimental Study of the Effect of Blade Angle on Pico Tubular Bulb Turbine Performance in Horizontal Flow," in International Conference on Industrial, Mechanical, Electrical, and Chemical Engineering 2019 (ICIMECE 2019), 2020, vol. 030122, no. April.

[12] Y. T. Budianto, A. D. Soewono, and M. Darmawan, "Rancang Bangun Mesin 3D Printer dan Laser Engraver Berbasis Arduino Yosef Teddy Budianto dkk / Jurnal Rekayasa Mesin,” vol. 15, no. 3, pp. 183-190, 2020.

[13] A. Z. Supraba, S. I. Cahyono, D. A. Himawanto, and D. D. D. P. Tjahjana, "Redesign runner turbin pembangkit listrik tenaga pico hydro dengan metode reverse engineering melalui pendekatan teoritis," JTMI, vol. 12, no. 2, pp. 61-65, 2016.

[14] H. Khuluqi, S. Hadi, and D. Danardono, “Analisis Simulasi Pengaruh Ratio Overlap Sudu Terhadap Unjuk Kerja Savonius Horizontal Axis Water Turbine,” Mek. Maj. Ilm. Mek., vol. 17, no. September, pp. 1-5, 2018.

[15] A. D. Mustaqiem and Nurato, “Analisis Perbandingan Faktor Keamanan Rangka Scooter Menggunakan Perangkat Lunak Solidwork 2015,” J. Tek. Mesin, vol. 09, no. 3, pp. 164-172, 2020.

[16] R. Khare and V. Prasad, "Effect of Solidity on Flow Pattern in Kaplan Turbine Runner," vol. 6, no. 2, pp. 602606, 2015. 